\title{
TURKEY'S ACCESSION TO THE EUROPEAN UNION: DOES CULTURE AND IDENTITY PLAY A ROLE?*
}

\author{
Meltem Müftüler $B A C^{* *}$ \\ Evrim TASSKIN ${ }^{* * *}$
}

\begin{abstract}
It is a highly acknowledged fact that in the European Union's enlargement process, Turkey plays a highly interesting role and deserves analytical attention in terms of its theoretical and policy making implications. This fact has become more pronounced since the start of accession talks with Turkey on 3 October 2005. However, the opening of the Turkish accession talks marked the beginning of a new era in terms of defining what constitutes Europe and the European identity. It is for this reason that Turkey's accession to the EU should be evaluated within the larger framework of EU enlargement and the European integration process and goes beyond an analysis of bilateral relations. Thus, Turkey's ability to adopt the EU standards is only one aspect of the whole picture with the EU specific factors playing an equally important role. This paper argues that the enlargement process of the EU determines the boundaries of what is Europe and what is not and that Turkey's accession to the EU becomes the most important and visible line of demarcation in that aspect. This means that a candidate's accession negotiations to the EU are determined by perceptions of that candidate's fit into a predetermined European identity. That is why the Turkish case is important because it illustrates the ambivalent nature of Europeanness and attempts by member

* This article emanates from RECON (Reconstituting Democracy in Europe), an Integrated Project supported by the European Commission's Sixth Framework Programme (contract no. CIT4-CT-2006-028698).

** Professor of International Relations and Jean Monnet Chair ad personam at Sabanci University, Faculty of Arts and Social Sciences.

${ }^{* * *}$ Ph.D Student at Sabancı University, Faculty of Arts and Social Sciences.
\end{abstract}


states to clearly define it. The purpose of this article is to analyze to process of enlargement from the sociological/constructivist approaches with regard to enlargement in general and towards Turkey in particular.

Key Words: EU Enlargement, Culture, Turkey-EU Relations

\section{$\ddot{O Z Z E T}$}

Birçoklarl tarafindan da kabul edildiği üzere, Türkiye, Avrupa Birliği genişleme sürecinde oldukça ilginç bir role sahip. Gerek teoride, gerekse bu sürecin pratikteki siyasi yansımalar göz önüne alındığında, Türkiye'nin AB'ye katılımını analitik bir çerçevede incelenmesi adeta bir zorunluluk arz etmektedir. Bu zorunluluk, 3 Ekim 2005 'te Türkiye'nin AB ile müzareke görüşmelerine başlamasıyla daha da vurgulanır oldu. Ancak, Türkiye ile müzakerelerin başlaması, Avrupa'y tanımlayan değerlerin ve ilintili olarak da Avrupalı kimliğinin de sorgulanacağ müteakip yeni bir dönemin başladığının habercisi oldu. Bu nedenledirki zaten, Türkiye'nin AB'ye katılımı, ikili ilişkiler lensinden uzaklaşslarak, daha geniş bir teorik çerçeveye tekabül eden $A B$ genişleme ve entegrasyon süreci içinde analiz edilmelidir. Böyle resmedildiğinde, Türkiye 'nin AB standartlarına uyum sağlayabilmesi kadar, $A B$ 'ye özgü etmenlerinde bu süreçte eşit derecede etkili olacă̆ unutulmamalıdır. Bu makalede, AB genişleme sürecinin Avrupa'yı tanımlayan eksenin hudutların çizdiği ve Türkiye'nin AB'ye katılım sürecinin de bu kapsamda en önemli ve en görünür kavşak noktast olduğu savunulmaktadır. Diğer bir ifadeyle, aday ülkenin AB ile müzakere süreci, sözkonusu ülkenin önceden tanımlanmış Avrupalı kimliğiyle ne kadar bağdaştığının algısına bağlı olarak değişeceği savunulmaktadır. Türkiye örneğinin ışı tuttuğu önemli bir gerçekli varki; o da, Avrupalı kimliğinin muğlak bir doğaya sahip olduğu ve AB ülkelerinin bunu daha net bir zemin üzerine oturtarak tanımlamak için çabalamaları gerektiği.Bu nedenle, bu makalenin amacı, bir bütün olarak genişleme sürecini ve bu bütün önemli bir parçasınt teşkil eden Türkiye'nin AB'ye katılım sürecini, sosyolojik/yapisalcı yaklaşımlardan faydalanarak analiz etmektir.

Anahtar Kelimeler: AB Genişlemesi, Kültür, Türkiye-AB İlişkileri

\section{Introduction}

The question of Turkey's accession to the EU has occupied the European leaders in an increasing fashion since 1999. However, since October 32005 the opening of accession negotiations between Turkey and the EU has radically changed the nature of this question. The intense reform process in Turkey in an attempt to fully adopt the EU's acquis communautaire and the European political standards led to the European Commission's recommendation in 2004 to begin accession negotiations with Turkey. This paper argues that Turkey's accession to the EU should be evaluated within the larger framework of EU enlargement and the European integration process and goes beyond an analysis of bilateral relations. Thus, Turkey's ability to adopt the EU 
standards is only one aspect of the whole picture with the EU specific factors playing an equally important role.

On May 1 2004, the EU has completed its most important wave of enlargement when 10 new countries mainly from the Central and Eastern Europe joined the EU. This was the fifth and the most extensive round of enlargement for the EU. The 2004 enlargement of the EU has not only affected the political and economic shape of Europe, but it also changed the institutional set up of the EU and the course of European integration. As a result, since the end of the Cold War in 1989, the importance and priority attached to enlargement by the academic circles and the key policy makers started to increase in an unprecedented fashion. In the enlargement process, Turkey plays a highly interesting role and deserves analytical attention in terms of its theoretical and policy making implications. When negotiations with Turkey began on October 3 2005 , it marked the beginning of a new era in terms of defining what constitutes Europe and the European identity. This paper argues that the enlargement process of the EU determines the boundaries of what is Europe and what is not and that

Turkey's accession to the EU becomes the most important and visible line of demarcation in that aspect. This means that a candidate's accession negotiations to the EU are determined by perceptions of that candidate's fit into a predetermined European identity. That is why the Turkish case is important because it illustrates the ambivalent nature of Europeanness and attempts by member states to clearly define it. The purpose of this article is to analyse to process of enlargement from the sociological/constructivist approaches with regard to enlargement in general and towards Turkey in particular.

Since the 2004 Brussels European Council Meeting, in which the decision on the formal opening of negotiations between Turkey and the EU was taken, "opponents to enlargement have invoked a supposed historical and cultural identity, especially with regard to Turkey." The perceived impact of Turkish accession to the EU has thus become quite apparent in both the political elite level and the societal level in Europe. It is at this stage in which cultural, ideational, and religious factors come into the scene. Prior to this stage, objections to the Turkish membership were primarily based on economic and political considerations. Debates as regards to Turkey's Europeanness were not yet on the table of the EU. According to Ziya Onis, "European approach to Turkish-EU relations was that Turkey was economically backward and, at the same time, had failed to satisfy the criteria in relation to democratization and human rights necessary to qualify for full membership in the foreseeable future." ${ }^{22}$ With the reform process in economics since 2001 and in the political system since 2002, Turkey was able to overcome most of the obstacles and fulfill the EU criteria in its economic and

\footnotetext{
${ }^{1}$ Mayer, F. C. and Palmowski, J., "European Identities and the EU-The Ties that Bind the Peoples of Europe", Journal of Common Market Studies, Vol. 42, No. 3, 2004, p. 593.

${ }^{2}$ Onis, Z., "Turkey, Europe, and Paradoxes of Identity: Perspectives on the International Context of Democratization", Mediterranean Quarterly, Vol. 10 (March 1999), p. 107.
} 
political aspects. As a result, when the EU opened the accession talks with Turkey on October 3 2005, upon the Turkish fulfillment of the Copenhagen criteria, debates "concerning the various dimensions of European identity and the boundaries of and the ambiguities surrounding the European project" have sharply increased in number, rather than Turkey's ability in fulfilling the EU accession criteria. Thus, since 2005, "Turkish accession to the EU has [thus far] become one of the most politically contentious issues in Europe". Almost every political actor in Europe has a stance on this issue. Nonetheless, it is worth to point out the fact that debates over Turkey, "and the broader issues surrounding membership, reveal much about what Europeans hope the 'New Europe' will become". Thus, this paper proposes that the Turkish accession to the EU is going to be determined by the extent to which it is perceived to be part of the European identity. Given the various objections coming from various quarters in the EU such as the French presidential candidate Nicolas Sarkozy's declaration that "Turkey's place is not in the EU", ${ }^{6}$ the main obstacle in Turkey's negotiations seems to be precisely this perception. The sociological institutionalist school with its emphasis on collective identity formation plays an important role in furthering our understanding in this aspect.

\section{Sociological Institutionalism and Its Possible Insights into Turkey-EU Relations}

Sociological institutionalism rests on the assumption that the logic of appropriateness means players while making up their minds, do not only take into account what is good for them but also what they are expected to do, that is to say, the roles and norms to be applied. It might suggest both rule-following due to habitual practices or particular identity and rule-following based on a rational assessment of morally valid arguments. ${ }^{8}$ Here the causal mechanisms suggested to clarify how norms and principles can have an impact on negotiation or bargaining process alter depending on the theoretical frameworks. Sociological institutionalism emphasizes the building and reshaping effects of principles and norms on social actors to such an extent that norms and conventions of the institutional setting become embedded in the minds of the members of the institution. Thenceforwards, preferences of the social players are set in accordance with those norms and principles. And eventual outcome of this interaction is that decisions are inevitably taken in line with those 'constructed' preferences." "Within

\footnotetext{
${ }^{3}$ Ibid., p. 109.

${ }^{4}$ Kubicek, P., "Turkish Accession to the European Union: Challenges and Opportunities", World Affairs, Vol. 168, No. 2 (Fall 2005), p. 71.

${ }^{5}$ Ibid.,

${ }^{6}$ Owen Matthews, "How Europe Lost Turkey”, Newsweek, December 112006.

${ }^{7}$ For further information see March, J. G. and Olsen, J. P., Rediscovering Institutions: The Organizational Basis of Politics, New York: Free Press, 1989.

${ }^{8}$ Eriksen, E. O., "Towards a Logic of Justification: On the Possibility of Post-National Solidarity", in Egeberg, M. and Laegreid, P. (eds.) Organizing Political Institutions: Essay for Johan P. Olsen (Oslo: Scandinavian Press), pp. 215-44 as cited in Sjursen, 2002, p. 494.

9 For a deeper analysis see Parsons, W., "Theories of the Policy Process", Journal of European Public Policy, Vol. 7, No. 1 (2000), p. 126-130 and Johnston, A., "Treating International
} 
this approach, the rationality of the actors is considered contextual, rather than instrumental, and deriving from the identity of the community they belong to." 10 As March and Olsen puts it "human actors are imagined to follow rules that associate particular identities to particular situations." "In a similar vein, the criteria for social action justification rely on values stemming from a particular cultural context and salient concerns of the decision-making process have to do with the search for collective self-understanding and the building of a common identity, which can serve as the basis for developing stable goals and visions. Collective decisions are a matter of identity, rather than efficiency, seeking to develop and protect the sense of 'we-ness' and to establish bonds of solidarity. ${ }^{12}$

In line with this argument, "this puzzle is solved through a sociological perspective in which enlargement is understood as the expansion of international community. If the $\mathrm{EU}$ is conceived of as the organization of the European liberal community of states, its decision to open accession negotiations with five Central and Eastern European countries can be explained as the inclusion of those countries that have come to share its liberal values and norms." 13 Institutions -which are defined in a rather broad term in sociological institutionalism in comparison with the rational account-, turn out to be the instrument through which the world is made meaningful to actors. For sociological institutionalists, "interests and identities are endogenous to (emanate from within) the processes of interaction that institutions represent. Interests as well as the contexts of action are socially constructed-given meaning to actors-by institutional norms and conventions." 14 To sum up, this view clearly represents the belief in "capacity of cultural and organizational practices (institutions) to mould the preferences, interests and identities of actors in the social world (hence sociological institutionalism)."

As Schimmelfennig and Sedelmeier have already argued "rationalism and constructivism do not provide us with fully elaborated and internally consistent competing hypotheses on enlargement that we could rigorously test against each other." 16 Therefore it is wise to perceive rationalist and sociological/constructivist theories of institutions "as partially competing and partially complementary sources of theoretical inspiration for the study of enlargement."17 The enlargement process has turned out to be a significant area to test, elaborate or falsify contending theories of

Institutions", International Studies, Vol. 45, pp.487-515.

${ }^{10}$ Piedrafita, S., and Torreblanca, J. I., "The Three Logics of EU Enlargement: Interests, Identities and Arguments", Politique Européenne, No. 15 (Winter 2005), p.34.

${ }^{11}$ March and Olsen, 1989, p. 951.

${ }^{12}$ Piedrafita and Torreblanca, 2005, p. 34.

${ }^{13}$ Ibid., p. 47-8.

${ }^{14}$ Rosamond, B., Theories of European Integration, New York: St. Martin's Press, 2000, p.119.

${ }^{15}$ Ibid., p.114.

16 Schimmelfennig, F. and Sedelmeier, U., "Theorizing EU Enlargement: Research Focus, Hypotheses, and the State of Research", Journal of European Public Policy, Vol.9, No.4 (August 2002), p.508.

${ }^{17}$ Ibid., 
rationalist and constructivist/ sociological institutionalism. ${ }^{18}$ It is possible to argue that they are based on different social ontologies (individualism and materialism in rationalism and ideational ontology in constructivism) and assume different logics of action: a rationalist logic of consequentiality opposed to constructivist logic of appropriateness. ${ }^{19}$ These two contending visions about the status and purposes of institutions inevitably influence our theorizing enlargement in its entirety. Hence, the conditions, assumptions and mechanisms of enlargement have to be different according to the chosen logic at work.

Accordingly, different status of institutions conceptualized in these two approaches also reflects itself in the importance attached to international organizations. "Rationalist institutionalism emphasizes the instrumental, regulatory, and efficiencyenhancing functions of international organizations." ${ }^{20}$ It would be fair to say in this context rational account views institutions as a significant constraint upon selfinterested action. On the other hand, sociological institutionalism views "institutions as autonomous and powerful actors with constitutive and legitimacy-providing function.,"21 In line with this logic, it is possible to arrive at this conclusion: "international organizations are "community representatives" as well as community-building agencies. The origins, goals, and procedures of international organizations are more strongly determined by the standards of legitimacy and appropriateness of the international community they represent (which constitute their cultural and institutional environment) than by the utilitarian demand for efficient problem-solving., 23

Sociological institutionalists argue that action of the social players are motivated through the rules of appropriate behavior, adapted into institutional setting in which norms/rules are ensued due to the sheer fact that they are perceived to be natural, expected and the right thing to do. However, what is not to be forgotten at this point is that the expansion of the liberal community on the basis of constitutive Pan-European

\footnotetext{
${ }^{18}$ In order to see some of the examples in theorizing Eastern enlargement of the EU, see Fierke, K. M. and Wiener, A., "Constructing Institutional Interests: EU and NATO Enlargement", Journal of European Public Policy, Vol.6, No.5 (1999), pp.721-42; Friis, L. and Murphy, A., "The European Union and Central and Eastern Europe: Governance and Boundaries", Journal of Common Market Studies, Vol. 37, No.2, pp.211-32; Schimmelfennig, F., "The Community Trap: Liberal Norms, Rhetorical Action, and the Eastern Enlargement of the European Union", International Organization, Vol.55, No.1 (Winter 2001), pp.47-80.; Schimmelfennig, F. and Sedelmeier, U., "Theorizing EU Enlargement: Research Focus, Hypotheses, and the State of Research", Journal of European Public Policy, Vol.9, No.4 (August 2002), pp.500-28 and Sjursen, H., "Why Expand? The Question of Legitimacy and Justification in the EU's Enlargement Policy" Journal of Common Market Studies, Vol.40, No.3 (2002), pp.491-513.

${ }^{19}$ March and Olsen, 1989, p. 160.

${ }^{20}$ Ibid.,

${ }^{21}$ Ibid.,

${ }^{22}$ Abbott, K. and Snidal, D., "Why States Act Through Formal International Organizations", Journal of Conflict Resolution, Vol. 42, No. 1 (1998), p. 24 as cited in Schimmelfennig and Sedelmeier, 2002, p.509.

${ }^{23}$ Schimmelfennig and Sedelmeier, 2002, p.509-10.
} 
rules takes its roots from sociological institutionalists who basically claim that actors act not only according to exogenously determined utility functions but also according to the values and norms that are endogenous to the process of social interaction.

In an institutional environment like the EU, political actors are concerned about their reputation as members and about the legitimacy of their preferences and behavior. Actors who can justify their interests on the grounds of the community's standard of legitimacy are therefore able to shame their opponents into norm-conforming behavior and to modify the collective outcome that would have resulted from constellations of interests and power alone. ${ }^{24}$

In a similar fashion, Sjursen argues that "norms constitute the identity of the actors: they not only constrain their behavior, but also constitute their world-views and preferences. It is on this basis that enlargement must be understood," ${ }^{, 5}$ Ethical-political reasons which basically refer to a feeling of shared identity, common history, political values, and sense of we-ness are the main driving forces behind the Eastern enlargement. In other words, sense of kinship-based duty has played a key role in mobilizing the member states for enlargement. But at this point it has to be noted that the critical point is how rules, principles, norms become embedded in the minds of social actors? Thomas Risse points out the role of communicative action: "the processes by which norms are internalized and ideas become consensual...communicative processes are a necessary condition for ideas to become consensual (or fall by the wayside for that matter). ${ }^{26}$ Hence, it is possible to argue that theories of communicative action which heavily draws from the work of Jürgen Habermas ${ }^{27}$ concentrate on processes of deliberation and argumentation, which are in turn perceived as manufacturing the basic epistemic 'glue' that binds actors together. ${ }^{28}$ According to "Habermas' theory of communicative action, actors are rational when they are able to justify and explain their actions, and not only when they seek to maximize their own interests." 29 This is very much in line with the logic of appropriateness as opposed to the logic of consequentiality. "The perennial issues of 'what is Europe' and 'who can the EU legitimately claim to represent' inevitably arise with enlargement." ${ }^{30}$ It is however, highly problematic to give a precise answer to the question of where Europe starts and ends and what is the EU's collective identity.

\footnotetext{
${ }^{24}$ Ibid.,

${ }^{25}$ Sjursen, 2002, p.491.

${ }^{26}$ Risse-Kappen, Thomas, "Exploring the Nature of the Beast: International Relations Theory and Comparative Policy Analysis Meet the European Union", Journal of Common Market Studies, Vol. 34, No. 1 (1996), p. 69.

${ }^{27}$ See Habermas, J., "On the Pragmatic, the Ethical, and the Moral Employments of Practical Reason", in Justification and Application: Remarks on Discourse Ethics, (Cambridge MA: MIT Press, 1993), p. 1-17.

${ }^{28}$ Rosamond, 2000, p. 121.

${ }^{29}$ Sjursen, 2002, p.493.

${ }^{30}$ Ibid., p. 501.
} 
This is precisely why the Turkish case is highly important to illustrate the validity of sociological institutionalism. The accession of Turkey to the EU will be one of most important steps in clarifying who the Europeans are once and for all. This is also why there is so much hesitancy among some EU members precisely because of Turkey's membership's impact on Europeanness.

\section{The Borders of Europe}

Europe is a geographical region which gave birth to construction of a particular civilization. In the formation and construction of this civilization, the Roman Empire and Christianity played constitutive and unifying roles in binding the peoples of Europe together. Despite the fact that the Reformation might have broken the seemingly harmonious state of unity in religion; however, Christianity has never ceased to serve for the greater good of the European intellect. ${ }^{31}$ Subsequently, Enlightenment with its emphasis on rationality and individualism engendered an unprecedented process of development in Europe in science and technology. In other words, Enlightenment and modernization went hand in hand. The peoples of Europe-albeit experiencing the Enlightenment and modernization in different times-witnessed "the transformation of rural, subsistence economies and feudal patriarchal political systems into industrialized democratic systems. ${ }^{32}$ However, being European does not only refer to living in a particular region of the world-i.e. Europe-but also refers to sharing and practicing of a common history, norms, traditions and values.

The difficulty of defining the borders of Europe has led to the emergence of the European Union membership as the most concrete indicator of Europeanness. Thus, it is no surprise that current twenty-five members of the EU are key players in creating the concept of Europeanness. The members of the EU share a common understanding of the past along with a common heritage. For so many times in history, economic and social practices made them closer; but at the same time cultural and historical specificities made them foes and rivals. In this common heritage, Europeans have witnessed several important events such as the Reformation, the Renaissance, the Enlightenment, the industrialization, the birth of nation-state and democracy. Aforementioned events were not only 'essential' and 'revolutionary' per se in the history of Europe but also crucial and constitutive in the world history.

In a very broader sense, at the risk of oversimplification, the European Union as we know it today can be viewed as the latest product of the peoples of Europe. Modernization, which is oft-identified with Europe, started to spill over to the rest of the world. "Historical points of convergence, common experiences and the development of a particular appraisal of the world, humanity and life itself went beyond underlying

\footnotetext{
${ }^{31}$ As regards to Christianity, it has to be reminded the reader that both Judaism and Islam have been crucial in shaping the European civilization.

${ }^{32}$ Nas, C. "Turkey-EU Relations and the Question of Identity", in The European Union Enlargement Process and Turkey (eds.) Muzaffer Dartan, Cigdem Nas, Publication of Marmara University European Community Institute, 2002, p. 219.
} 
cultural and ethnic differences". ${ }^{33}$ These differences, rivalries, enmities throughout all European history have to a certain degree been instrumental in shaping the political and cultural map of Europe. At this point, Jewish, Arabic and Ottoman influences are worth mentioning in Europe's search for the 'other'. Following the same line of reasoning, it is thus reasonable to interpret European history and Europe as an end result of the interplay of the commonalities and differences engendered by Europeans themselves as well as non-Europeans. These diverging and converging points gave birth to the genesis and continuity of European thought and culture.

Agnes Heller points out that "Europe takes the other, transforms it and makes it own." ${ }^{\text {"I4 }}$ In accordance with the idea of a 'unified and integrated Europe', it is possible to argue that the very existence of external threat and the urgent need to defend themselves against the threat compelled Europeans to think and act in harmony. ${ }^{35}$ For most of the time, the source of the threat was the East: (i) Arabic invasions to the Iberian Peninsula; (ii) Ottomans march to the doors of the Central Europe; (iii) the hegemony of the Soviet Union in Eastern Europe. ${ }^{36}$ Europe's other has always been subject to change according to evolving nature of the European circumstances. In other words, " $[\mathrm{t}]$ he importance of external recognition varies, but at its most extreme it is a crucial determining factor in the creation of identities." 37 As David McCrone points out "nor are national cultures and identities fixed and immutable. They are subject to processes of translation and change." 38 The same point of view has also been advocated by Mayer and Palmowski. In a similar fashion, they argue that "[i]dentities are constructed and mediated constantly, and they require acceptance both within and from without." 39 Accordingly, the same logic can also be applied to the formation of the European identity. Thus the particular conception of Europe should not only be constructed on the basis of a common reading of the past and homogeneous culture. Despite the fact that, "others of the Europe' have played a significant role in construction of the self-definition of Europe, it is better to remind that being European is also defined through "forgetting as much as remembering", 40

One needs to point out that European identity is yet to prevail over the national identities which are still at the fore front and do not appear to be eroding in favor of the newly emerging European one. In this context, European identity is a new layer of selfidentification, added on top of national identities without necessarily challenging them. The latest debates indicate that there is no actual trade-off between the national and European identities. In this sense, as Hooghe and Marks point out, there is a positive

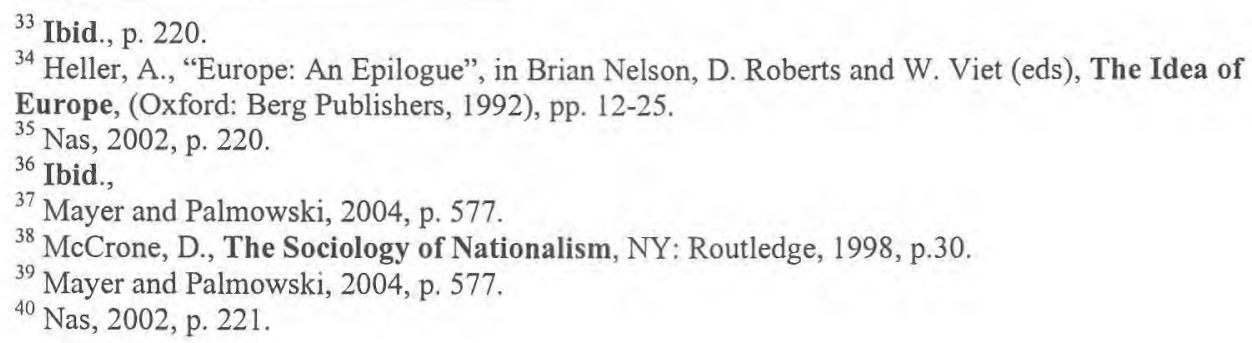


correlation between attachment to one's own country and support for European integration. $^{41}$ By the same token, Bruter claims that the more an individual defines oneself with his/her nationality, the more he/she associates himself/herself with Europeanness. $^{42}$

One final point still demands an urgent attention. "Identification with the European continent has always been linked to the continent's history, geography and culture. However, the current, particular ... meanings of a European identity have been reshaped, expressed and amplified through the process of European integration since the 1950s., ${ }^{, 43}$ It is actually the case because the supra-level European identity revolves around the EU. Therefore, the roots of the European identity, as we know it today, can be traced in the political and legal aspects of the EU. "[T]he EU can at most be characterized by an attempt to build civility codes of identities by reutilizing new practices and rituals in a European sphere of communication and identification with key values and institutions." 44 In accordance with Bartolini's point that only the acquired rights and traits can be the base of Europeanness; and, thus, the fundamental elements of European identity are declared in the Document on the European Identity is to be a society which measures up to the needs of the individual representative democracy, rule of law, social justice and respect for human rights. ${ }^{45}$ In other words, European identity should be inclusive in the sense that "[ $\mathrm{t}$ ]he factors that make the difference between being European and not-on the margins of Europe-involve sharing a particular set of values, socio-economic development and societal organization." 46 Therefore, "[c]ommon understandings, values, norms and interests will constitute the basis of liberal community" in which the peoples of Europe live". ${ }^{47}$

This is why European identity sits at the very core of the EU's enlargement process. EU membership implies being a part of the European integration process through the sharing of burdens and benefits emanating from the membership. Accordingly, while deciding on decision to expand, the EU sets its own agenda and its own priorities. Thus countries excluded from the successive enlargement rounds will be the ones whose Europeanness is not acknowledged or in question. What is significant and clear is that "the European collective identity promoted by the EU is hybrid in terms

\footnotetext{
${ }^{41}$ Hooghe, L. and Marks, G., "Does Identity or Economic Rationality Drive Public Opinion on European Integration?" PS-Political Science and Politics, Vo. 37, No. 3, (July 2004), p. 417.

${ }_{42}$ Bruter, M., "Institutions, Media \& the Emergence of European Identity" İstanbul: Sabanc1 University, 29 January 2005.

${ }^{43}$ Mayer and Palmowski, 2004, p. 592.

44 Bartolini, S., Restructuring Europe: Centre Formation, System Building and Political Structuring between the Nation State and the European Union, Oxford: Oxford University Press, 2005, p.215.

${ }^{45}$ Article I-I of the Document on the European Identity.

${ }^{46} \mathrm{Nas}, 2002$, p.221.

${ }^{47}$ Ibid.,
} 
of embodying both inclusive and exclusive aspects." ${ }^{\text {48 }}$ Therefore the newly-emergingpolitical map of Europe will set the demarcation line between the Europeans (i.e. insiders) and non-Europeans (i.e. outsiders).

In this critical juncture, Turkish membership to the EU has to be analyzed through the lenses of identity and culture so as to shed light onto the ongoing debate on Turkey's Europeanness and Europeans willingness to embrace Turkey as a new member in the EU.

\section{Turkey as Europe's Other}

Turkey's Ottoman past still casts shadows over its present day relations with Europe. Since the end of World War II, Turkey has been in a close relationship with Europe. Nonetheless, despite the existence of decades long relationship with Europe, Turkey's Europeanness has always been a controversial issue. Turkey's own internal ambiguities regarding its identity and Europe's own confusion in shaping its newly emerging identity are the factors that complicate Turkey's fit into Europe.

It is important to note that Turkey's past relations with the European states since the $15^{\text {th }}$ century played a crucial role in shaping the European perceptions of the 'Turk'. The Ottoman Empire and its Muslim identity as opposed to Christian Europe have been crucial in shaping the minds of Europeans in conjunction with the Turkish membership to the EU. In particular, when one starts considering the civilizational dimension of the European integration project, ideational and religious factors inevitably come to the forefront. Not surprisingly, the demarcation lines between the insiders and outsiders start growing bolder. For example, "Europe represented 'civilised' world and the Ottomans belonged to the 'barbaric' world. It was claimed that the 'Turk' possibly did not belong to the progressive races of mankind,"49

In the context of contemporary Europe's self definition and the other; according to Ziya Onis, "Christianity is a key component of European identity, even though it may not be its principal or overriding constituent." ${ }^{, 50} \mathrm{He}$ goes further and argues that "[i]n the EU's relations with Turkey, this dimension of the European identity comes to the surface and plays a major determinant role." ${ }^{, 51}$ Similarly, Meltem Müftüler Baç argues that Turkey's relations with the EU is one of binary opposition and one of the major obstacles to Turkey's EU membership. ${ }^{52}$

\footnotetext{
${ }^{48}$ Rumelili, B., "Constructing Identity and Relating to Difference: Understanding the EU's Mode of Differentiation”, Review of International Studies, Vol. 30, 2004, p. 44.

${ }^{49}$ Neumann, I. and Jennifer Welsh, 'The Other in European Self-definition: An Addendum to the Literature on International Society', Review of International Studies, Vol.17, 1991, p.344.

${ }^{50}$ Onis, 1999 , p. 113.

${ }^{51}$ Ibid.,

52 Müftüler-Baç, M., "Through the Looking Glass: Turkey in Europe", Turkish Studies, Vol.1, No.1, Spring 2000, pp.21-35.
} 
Having said that "Christian-Muslim divide is ...a central line of demarcation between Turkey and contemporary Europe", it is relevant to goes back in history to find the traces of this demarcation. ${ }^{53}$ As has also been stated by Mayer and Palmowski, it is worth to look back at history in the sense that "[w]ith the current wave of enlargement, a European identity has largely been constructed on historic grounds." 54 In this context, it is possible to argue that "for more than 500 years Europe defined itself partially in opposition to the Ottoman Empire, asserting an historic identity for Europe would have profound implications for the question of Turkish accession." 55 The first meeting of Europeans with Muslim civilization can be assumed to take place in battles at Tours/Poitiers in the eighth century. Some two hundred years later -through the crusades-confrontation of Christians with the Muslims started growing tense and violent. Finally, with the second siege of Vienna in 1683, this confrontation reached its climax. Therefore, these historical experiences of Europeans with the Muslim world still have contemporary influence in the minds and hearts of the peoples of Europe. ${ }^{56}$ In this sense, the Ottoman Empire was obviously a critical player in European politics; however, for most of the time, the Ottomans' confrontations with Europe were always almost hostile and violent. In addition, the Ottomans did not exert themselves too much to develop more substantial and closer ties with Europeans in the areas like culture, economics or even in diplomacy. ${ }^{57}$ According to Mayer and Palmowski, [i]t is through interaction with each other and with outsiders that individual and group identities are constructed. Certain base co-ordinates such as geographic and familial origin are given, but they obtain their individual meanings through the emotional content gained in interaction with others. ${ }^{58}$

The emotional content in the EU-Turkey relations were already existent in conjunction with the Ottoman past of the Turks. As already mentioned "[e]vents such as two Ottoman sieges of Vienna did much to imprint a view of the Turks on Europeans, so that in Said's terms, Turks (and Muslims more generally) were defined as 'the other' by Europeans and imbued with a host of negative traits (for example, 'uncivilized', 'barbaric', 'heathen'). ${ }^{.59}$ This is also why the barbaric invader image of Turks emerges in the speeches of European officials and leaders from time to time such as in the speech delivered by Frits Bolkestein, then European Union Commissioner responsible for the Internal Market, at the Leiden University in September 2004 where he stated that

${ }^{53}$ Onis, 1999, p. 107.

${ }_{55}^{54}$ Mayer and Palmowski, 2004, p. 574.

${ }^{55}$ Ibid., p. 575.

${ }^{56}$ Dombey, D. "Turkey's Legacy Casts Long Shadow over Talks with EU”, Financial Times, September 62004.

${ }^{57}$ For the falling short and/or omission of the Ottomans in establishing close engagements with Europeans, see Lewis, B., What Went Wrong? (Oxford: Oxford University Press, 2002). For a critical discussion of Turkish history, see Zurcher, E., Turkey: A Modern History, (London: I. B. Tauris, 2004).

${ }_{58}^{58}$ Mayer and Palmowski, 2004, p. 577.

${ }^{59}$ Kubicek, 2005, p. 68. For further information on Europe's definition of its other and critique of Euro-centric view, see Said, E., Orientalism, New York: Vintage, 1979. 
"If Turkey accedes to the EU, then this means that the efforts of the German, Austrian and Polish troops that resisted the Ottoman Turks' siege of Vienna in 1683 would be in vain". 60

As of the nineteenth century, the Ottomans became the 'sick man of Europe' and World War One brought the collapse of the Empire. Nonetheless, hostile confrontations of the Ottomans with the Christian community in the Balkan Wars and in World War One did nothing but to make the Ottomans' image worse in the eyes of the Europeans and to a great extent strengthened the prejudices against the Ottomans with regard to their 'savagery'. When one follows the traces of the past, it is not hard to find 'hostile sentiments' against the Ottomans among the Europeans. Here is a simple manifestation of one of those 'hostile' sentiments against the Ottomans:

The primary and most essential factor in the situation is the presence, embedded in the living flesh of Europe, of an alien substance. That substance is the Ottoman Turk. Akin to the European family neither in creed, in race, in language, in social customs, nor in political aptitudes and traditions, the Ottomans have for more than five hundred years presented to the European powers a problem, now tragic, now comic, now bordering almost on burlesque, but always baffling and paradoxical. ${ }^{61}$

The systemic changes at the end of World War II began to change the Turkish position in the European order as well. The post war restructuring and emerging dynamics of the Cold War gave Turkey a specific role to play in the European order as the southeast bastion of its defense against Soviet expansionism. As a result, Turkey was an integral part of the European institutions that were created. Turkey first demonstrated its will to become a member of the EEC (i.e. now the EU) through a signing of an Association Agreement with the EEC in 1959. Since this day, "Turkey's status as a potential member has continuously evoked heated debate within the EU and remained at best ambiguous." ${ }^{22}$ Drawing from the above discussion about Turkey's being Europe's other, "an important asymmetry seems to be evident concerning its [i.e. Europe] approach to and treatment of insiders and outsiders." ${ }^{63}$ If one considers the recent enlargement of the CEECs, this reality comes to the surface and becomes much more visible. "It would not be possible to explain the differential treatment of the CEECs and Turkey, countries broadly at the same level of economic and political development, without reference to this factor." ${ }^{64}$ The EU did not display the same eagerness and goodwill towards Turkey as it did towards the CEECs.

60 "Turkish Accession: why frank discussion is vital", European Voice, Vol.10, No.30, 9 September 2004, p.9.

${ }^{61}$ Marriot, J. A. R., The Eastern Question, (Oxford: Clarendon, 1919), p.3 as quoted in Kubicek, 2005 , p. 68.

${ }^{62}$ Rumelili, 2004, p. 44.

${ }^{63}$ Onis, 1999, p. 112.

${ }^{64}$ Ibid., 
"The discourses that emphasize the exclusive aspect of European identity based on geography and culture construct Turkey as inherently different. On the other hand, the discourses that emphasize the inclusive aspects of European identity construct Turkey as different from Europe solely in terms of acquired characteristics."65

Thus, the debates about Turkish membership to the EU are related with Europe's own confusion and hesitancy about its own identity. Debates over Turkish membership are merely the asymmetrical reflections of ongoing debates on European identity, in which 'mess' and 'confusion' about the shared identity among Europeans is no longer possible to hide.

"[s]ince a European identity is not based on a common historical memory, it is difficult to argue that Turkey should be excluded on these grounds. As long as Turkey can fulfill the institutional, economic and legal requirements for membership, all of which are necessary to meet other conditions such as human rights, Turkey is not principally excluded from a European identity which has been shaped so decisively by the institutions and the law of the EU,"

Even though this constitutes the main factor in taking Turkey so far in the EU accession process, ideational factors play a significant role in determining the public's views on Turkey's accession. Because the question of shared identity of Europe heavily reveals itself in the polls made at the societal level; it is thus relevant to discuss the opinion of the EU citizens as regards to the prospective Turkish membership to the EU.

\section{Public Opinion: Support for Turkish Accession}

Since the latest enlargement round in May 2004, the public opinion in the EU towards further enlargement has changed in a negative direction "While $49 \%$ of the citizens of the EU are in favor of further enlargement of the EU in future years, $39 \%$ of the respondents oppose this." ${ }^{" 67}$ Several events have contributed to this decline in the popular will vis-à-vis the European integration: (i) rejection of the Constitutional Treat by the French and Dutch citizens in 2005; (ii) increasing rate of unemployment in several core EU member states; (iii) low rates of economic growth in the EU-25.

When framed as such, economic considerations might seem to affect the public attitude towards the accelerated integration. Beyond doubt, "[t]he main thrust of European integration has been to sweep away barriers to economic exchange, facilitate mobility of capital and labor, and create a single European monetary authority." ${ }^{\circ 8}$

\footnotetext{
${ }^{65}$ Ibid.,

${ }^{66}$ Ibid, p. 593.

${ }^{67}$ Standard Eurobarometer 64, "Public Opinion in the European Union", June 2006, p. 134.

${ }^{68}$ Hooghe, L. and Marks, G., "Does Identity or Economic Rationality Drive Public Opinion on European Integration?" PS-Political Science and Politics, Vo. 37, No. 3, (July 2004), p. 415.
} 
Therefore, it is no coincidence that economic factors play a major role in shaping the public opinion of the EU citizens. Looking back at the 2004 enlargement provides the simple fact that there were already clear reservations of the EU citizens as regards to the entrance of ten new members. The low level of economic development, concentration on agricultural sector, and the prospect of immigration to the core EU countries have been the characteristics of the state of nature of those states. The perceived impact of enlargement triggered an anxiety among the European public who were already suffering from the decline in economic performance in the European Union. All these economic arguments and concerns are also valid for Turkish membership. What is significant and determinant in the Turkish case is that fears and concerns of the EU citizens over Turkish membership are heavily impacted by the ideational, cultural and religious factors. These factors could be illustrated by an examination of public opinion in the EU towards Turkish accession through the Eurobarometer polls, the Special Eurobarometer and Standard Eurobarometer 64 of July 2006 are chosen for that purpose.

When the citizens of the EU are asked as regards to their choice of future members of the EU; the lowest level of support has been observed for Turkish membership to the EU. The question is as follows: "For each of the following countries, would you be in favor of against becoming part of the European Union in the future" ${ }^{69}$ Results can be summarized as follows: "The 77 percent of the EU citizens would like to see most Switzerland and Norway as future members of the EU. In other words, with 77 percent of support level coming from the EU citizens, Switzerland and Norway are at top of the list of the countries that are most wanted to be seen as future members of the EU." ${ }^{, 70} \mathrm{On}$ the other hand, with the 31 percent of support level, Turkey has been found to be the least desired country in the list of the EU citizens as to which country they would like to see as future member of the EU. ${ }^{71}$

The most critical question of the Special Eurobarometer survey assesses whether the citizens of the EU are willing to see Turkey as a future member when Turkey complies with the EU criteria. "Once Turkey complies with all the conditions set by the European Union, would you be... to the accession of Turkey to the European Union?",72 Results of the question are complied in Table 1 below:

\footnotetext{
${ }^{69}$ Standard Eurobarometer 64, 2006, p. 137.

${ }^{70}$ Ibid.,

${ }^{71}$ Ibid.,

${ }^{72}$ Special Eurobarometer 255, "Attitudes towards European Union Enlargement, Publication". June 2006, p.70.
} 
Table 1: Turkey's Accession Generates Approval or Disapproval?

1. $39 \%$ of the respondents are in favor of the Turkish accession while $48 \%$ oppose this.

2. The strongest opposition comes from countries like Austria (81\%), Germany (69\%) and Luxembourg $(69 \%)$ in which public opinion is already less in favor of enlargement.

3. On the other hand, Cyprus (68\%) and Greece (67\%) are also in disfavor of Turkey's accession although they are generally in favor of accession of other countries.

4. The strongest support comes from the Turkish Cypriot Community (67\%). Conspicuously, $54 \%$ of the Turkish citizens are in favor of their country's accession and $22 \%$ of them oppose it.

\section{Source: Special Eurobarometer 255, p.70-1.}

In this critical juncture, it is worthwhile to mention the positions of some EU member states vis-à-vis Turkish membership. However, before going deep down of the debate, there are some central points that still demand overall review. Liesbet Hooghe and Gary Marks point out the fact that "opposition to European integration is often couched as defense of the nation against control form Brussels. Radical right-wing parties in France, Denmark, Italy, and Austria tap nationalism to reject further integration, and since 1996 such parties have formed the largest reservoir of Euroskepticism in the EU as a whole,"

This analysis is especially true for the case of Turkey's EU membership. Members that are less in favor of further integration are also less in favor of Turkey's EU membership. For example, "[t]he German Christian Democrats (i.e. Christian Democratic Union and Christian Social Union) oppose Turkish accession together with Austria and several politicians in France, since it would 'overstretch' the EU."74 Namely, material considerations which are driven by logic of consequentiality (e.g. overstretching of the EU) might appear to work in opposition to Turkey's EU membership. The same logic lead those parties to suggest a 'privileged partnership' to Turkey as opposed to full membership. In other words, albeit in an implicit manner, historical and cultural differences seem to deteriorate the Turkish case. According to Francois Heisbourg of the French Foundation for Strategic Research, "[i]t is more or less spoken or more or less hidden, but the major component in popular rejection of Turkey's admission is Islam." ${ }^{75}$ Nonetheless, it has also to be noted that arguments about Turkey's cultural fit to Europe does not all come from the far-right political parties of Europe. For example, when former French Prime Minister Jean Marie Raffarin was asked in 2004 so as to comment about Turkish membership, he made the following remarks: "We are not doubting the good faith of Mr. Erdogan, but to what extent can today or tomorrow's government make Turkish society embrace Europe's

\footnotetext{
${ }^{73}$ Hooghe and Marks, 2004, p. 416

${ }^{74}$ Kubicek, 2005, p. 73.

75 Ford, P., "Wariness over Turkey's EU Bid", Christian Science Monitor, (October 6 2004) as quoted in Kubicek, 2005, p. 73.
} 
human rights values? Do we want the river of Islam to enter the riverbed of secularism?"”76

Although the overall picture might appear to give negative signals about the issue of Turkey's cultural fit to Europe; there are however some positive arguments which prove that Turkish accession is still an attainable goal. Former German Foreign Minister Joscka Fischer, once claiming himself to carry doubts about Turkish membership; has given the following statements after the "War on Terrorism": to modernize an Islamic country based on the shared values of Europe would almost be a D-Day for Europe in the war against terror, [because it] would provide real proof that Islam and modernity, Islam and the rule of law... [and] this great cultural tradition and human rights are after all compatible. ${ }^{77}$

To end the discussion on the public opinion about Turkish accession, nine statements, in which the EU public opinion as regards to Turkish membership are crystallized, are assumed to give valuable insights in this matter. Nine statements are produced from the answers given the subsequent question: "For each of the following please tell me you agree-\% EU" ${ }^{78}$. Results are complied in Table 2 below:

Table 2: Turkish Membership in the Eyes of the EU Citizens

1. "To join the EU in about 10 years, Turkey will have to respect systematically Human Rights": $83 \%$ agree and $7 \%$ disagree.

2. "To join the EU in about ten years, Turkey will have to significantly improve the state of its economy": $76 \%$ agree and $10 \%$ disagree.

3. "Turkey's joining could risk favoring immigration to more developed countries in the EU": 63 $\%$ agree and $23 \%$ disagree.

4. "The cultural differences between Turkey and the EU Member States are too significant to allow for this accession": $55 \%$ agree and $31 \%$ disagree.

5. "Turkey partly belongs to Europe by its geography": $54 \%$ agree and 35\% disagree.

6. "Turkey partly belongs to Europe by its history": $40 \%$ agree and $45 \%$ disagree.

7. "Turkey's accession to the EU would favor the mutual comprehension of European and Muslim values": $38 \%$ agree and $47 \%$ disagree.

8. "Turkey's accession to the EU would strengthen the security in this region": $35 \%$ agree and $48 \%$ disagree.

9. "Turkey's accession would favor the rejuvenation of an ageing European population": $29 \%$ agree and $50 \%$ disagree.

Source: Standard Eurobarometer 64, p. 139.

76 "Turkey's Francophiles Wounded by French EU Doubts" Turkish Daily News, September 12 2004, as quoted in Kubicek, 2005, p. 73.

${ }^{77}$ Kagan, R., "Embraceable EU”, Washington Post, 5 December 2004, as quoted in Kubicek, 2005 , p. 71.

${ }^{78}$ Standard Eurobarometer 64, 2006, p. 139. 
In view of the nine statements presented above, it is possible to argue that in the eyes of the EU public 'Turkey's accession should be contingent on the fulfillment of certain conditions": the systematic respect for human rights $(83 \%)$ and the significant improvement in the state of Turkish economy (76\%). In other words, as Hooghe and Marks have previously pointed out both the identity (in the form of cultural traits, and religion) and economic rationality impact the public opinion on further EU enlargement. ${ }^{79}$ Regarding the Turkish case, as the numbers clearly reveal, both the logic of consequentiality (implying to economic rationality) and the logic of appropriateness (referring to the shared identity, norms, values of the EU) appear to go hand in hand.

With respect to country profiles, Sweden, Finland, Belgium, Denmark, the Netherlands, Germany, Greece and Luxembourg are the countries in which there is already a tacit agreement on the view that Turkey will have to respect Human Rights in the following ten years. More than 9 out of ten respondents in those countries apparently adhere to this view. As for the case of Turkey itself, $69 \%$ of the Turkish respondents are in agreement that Turkey will have to demonstrate a systematic respect for human rights. ${ }^{80}$

As for the issue of economic improvement, there is almost unanimity among the respondents, $76 \%$ are in agreement with the view that Turkey will have to significantly improve the state of its economy. It is worth to remind that varying degrees of agreement among the countries seem to be arising from the 'don't know' responses which are tantamount to $14 \%$. The highest level of agreement in this matter can be observed in Greece (92\%), Finland (91\%) and Belgium (90\%). ${ }^{81}$

In reference to the discussion on further enlargement and the prospect of Turkish membership, the citizens of the Union in the final analysis are found to be displaying certain characteristics. See the following lines at the end of the Special Eurobarometer 2006;

Europeans surveyed recognize that EU enlargement will have positive consequences on mobility for Europe, the enrichment of cultural diversity, peace and stability, democracy, as well as the reinforcement of the EU's role on the international scene. In contrast, with regard to the economic and social consequences of the process, EU citizens worry most about employment. They fear an increase in labor transfer to countries where labor is cheaper, as well as expecting workers from future member states of the Union to settle in other EU countries...for future enlargement processes; apart from the low level of knowledge about the topic in general, benefits for the EU are less known compared to benefits for potential future member states. ${ }^{82}$

\footnotetext{
${ }^{79}$ Hooghe and Marks, 2004, p. 415.

${ }^{80}$ Standard Eurobarometer 64, 2006, p. 140.

${ }^{81}$ Ibid.,

${ }^{82}$ Special Eurobarometer 255, 2006, p. 74.
} 


\section{Conclusion}

This article attempted to analyze Turkish membership to the EU from the perspective of sociological institutionalism and argue that ideational and cultural factors play a very important role in Turkey's accession.

With regard to enlargement, rational institutionalists claim that players live in a world in which they seek to maximize their utility which is represented in the form of economic or security preferences. In case of conflict of interests, players utilize negotiations with the aim of distributing the benefits or accommodating the costs among themselves. Correspondingly, outcome of the negotiations is akin to manifest the distribution and asymmetries of power among the players. In a nutshell, both at the member state level and the applicant state, enlargement preferences are shaped by the calculation of expected cost-benefit of each individual state. Accordingly, each actor seeks to maximize the net benefits of its own. However, as Schimmelfennig and Sedelmeier argued "it is not necessary that enlargement as such is beneficial to each member. Enlargement can also result from unequal bargaining power among the incumbents. Member states that expect net losses from enlargement will agree to enlargement if their bargaining power is sufficient to obtain full compensation through side-payments by the winners (which, in turn, requires that the necessary concessions do not exceed the winners' gains from enlargement). Otherwise, the losers will consent to enlargement if the winners are able to threaten them credibly with exclusion (and if the losses of exclusion for the loser exceed the losses of enlargement)."

As opposed to rationalist account, sociological/constructivist institutionalism sees enlargement as shaped by the ideational, cultural factors. Therefore analysis of enlargement is tantamount to the analysis of social identities, norms, values, rules. ${ }^{84}$ Accordingly, enlargement politics inevitably focus on the "collective identity, the constitutive beliefs and practices of the community, and norms and rules of the organization. ${ }^{985}$ Obviously, Turkey's membership is not guaranteed. Turkey still has a lot to do on its way to the EU. Turkey's poor economic and political credentials are the main obstacles in front of Turkish accession to the EU. Turkey still needs further democratization in the political realm and the state of sustainable growth pattern in the economic realm. Stability and sustainability in both realms are assumed to help Turkey find its place in the international arena. It is no surprise that Turkish state needs to get into a profound and radical process of transformation in order to meet the EU demands throughout the entire accession process. Nonetheless, many commentators do not give up pointing out the 'differences' of Turkey in every occasion without taking into consideration the final stage arrived in Turkey-EU relations. Discussions on Turkey's not belonging to the European family or hints on its Islamism are part of EU criteria in front of the Turkish membership. "To assert that Turkey cannot be a member of the EU

\footnotetext{
${ }^{83}$ Schimmelfennig and Sedelmeier, 2002, p. 512-3.

${ }^{84}$ Ibid.,

${ }^{85}$ Ibid., p. 514.
} 
because of its culture and, especially, because it is Muslim, would be ... an intrinsic and insurmountable incompatibility with democratic values and respect for human rights". 86 Such claims on Turkish membership are mere reflections of Europe's own confusion, disorientation about its own identity. ${ }^{87}$ However, this seems to be where the debate mostly centers on. In other words, challenge is two-sided: one lies at the heart of the EU's itself. The prospect of Turkish membership will not only determine the future of Turkey but also that of the Europe's. Turkish identity and European identity are subject to change in accordance with the circumstances dictated by the nature of the relationship. The second challenge stands at the core of Turkish state in view of the fact that Turkey still needs to better its economic, societal and political conditions. Namely, , "the realization of the EU dream and, in part at least, its pursuit, require a process of transvaluation whereby the normative core of political activity and institutions in Turkey faces the need not simply to adapt but radically change."

\footnotetext{
${ }^{86}$ Torreblanca, J., “Europe's Reasons and Turkey's Accession”, Real Instituto Elcano ARI No. 199, 2004, p. 3.

${ }^{87}$ Ballin, E. H., "Europe's Borders and Basics: Where to Situate Turkey?", Lecture for the Center for European Studies, Bogazici University, and the Foreign Policy Forum, (Istanbul, 17 December 2004), p. 2.

${ }^{88}$ Glyptis, L., "The Cost of Rapprochement: Turkey's Erratic EU Dream as a Clash of Systemic Values", Turkish Studies, Vol. 6, No. 3 (September 2005), p. 402.
} 